

CAPTAIN JAMES ALLEN

From a photograph. 


\section{CAPTAIN JAMES ALLEN AND FORT DES MOINES}

Captain James Allen is given highest honor among those who had to do with the beginning of the city of Des Moines, for he it was who made the report to the War Department in favor of establishing the fort at the forks of the Des Moines and Raccoon rivers which was accepted by the department over the recommendations of Colonel S. W. Kearney and others against that location, and he it was who led the company of dragoons up the river in the spring of 1843 and established Fort Des Moines, which proved to be the beginnning of the capital city of the state. ${ }^{1}$

Captain Allen's report ${ }^{2}$ to the War Department favoring this location is a model in clearness of statement. It shows he had a thorough acquaintance with the adjacent territory, and he gives the advantages of this location over any other. The officers higher up believed in him and in his arguments.

In less than a year after he evacuated Fort Des Moines his sudden death occurred near Fort Leavenworth (August 23, 1846) when he was proceeding with his Mormon Regiment to enter the Mexican War. Thus ended at the age of 40 years what likely would have become a distinguished military career.

No picture of Captain Allen was believed to be in existence, until now, ninety years after his death when the Curator of this department received a photograph from which we have had made the accompanying illustration. It appears the photograph has been in possession of collateral relatives all these years. The following letter is explanatory:

First United Presbyterian Church Fourteenth Ave. and East Spring St. Seattle, Washington.

Curator Historical, Memorial and Art Department of Iowa, Des Moines, Iowa.

Dear Sir:

Enclosed please find an old photograph which I thought perhaps you might wish to have, and if so, that it ought to go to your department. It is that of Captain James Allen whose connection with the

\footnotetext{
1See article on Fort Des Moines No. 1, prepared at the War Department for the AnNALs of IowA, and published in Vol. III, pp, 351-63; also a similarly prepared article on Fort Des Moines No. 2 in Vol. IV, pp. 16i-78.

2 ANNALS, Vol. IV, pp. 161-66.
} 
earlier history of Iowa and of Des Moines, and especially his selection of the site of Fort Des Moines, now the city of Des Moines, led me to feel that it might be of interest to you.

I have noted on the back of the photo some items in regard to him and his family. His parents were James Allen (April, 1776-January 10,1848 ) and Jane Hethwood (April, 1775-Octobe: 4, 1815). They were natives of the North of Ireland, were married there and came to America in the year 1799. They lived in Ohio, I think in Brown County, and later in Indiana, probably in Franklin, Indiana, as they are both buried there. Of their children, two sons were cadets in West Point, and officers in the U. S. Army. James [born in 1806] whose photo is enclosed was a cadet at the Military Academy at West Point, July 1, 1825, brevet second lieut., and second lieut. Fifth Inf. July 1, 1829; second lieut. First Dragoons, March 4, 1833; first lieut. may 31, 1835; capt. June 30, 1837. He died August 23, 1846. As to his connection with early Iowa history and his selection of the site of Fort Des Moine: (the second of that name in Iowa as I have it) and of his death while raising a regiment or part of one from among the Mormons, you will have all the information that $I$ have and much more.

His brother, Robert Allen (1815-August 6, 1886), was in the Seminole War, served as second lieut, in the Mexican War and was made brevet major. Later he was chief quartermaster of the Department in the West, and superintendent of supplies and transportation in the Mississippi Valley, 1861-1865. Fitted out Sherman's Expedition to Chattanooga, \&c., chief quartermaster of the Pacific Div., 1866-1869; senior asst. in the quartermaster general's office, Washington, D. C., in 1869, and retired in 1878 . He was made brevet major general in 1865 .

Of interest also may be the fact that B. F. Allen, prominent in financial affairs in Des Moines and in Iowa in the earlier days, was a nephew of Captain Allen, a son of his brother, John Allen.

This photo came some years ago to my wife, Mary Allen Sawhill (now deceased), a daughter of the late J. C. Allen of Dexter, Iowa, whose father was Alexander Allen, an older brother of Captain Allen. It was sent to her by Miss Alice Finch, of Indianapolis, Indiana, whose mother, Mrs. Judge F. M. Finch of Indianapolis, was a sister of Captain Allen.

With grateful memories of my native state, the home of my parents during all their married life (Rev, and Mrs. James Sawhill of Winterset) and with best wishes for her welfare,

I am, sincerely yours,

W. R. SawhiL.

August 15, 1936. 
Copyright of Annals of Iowa is the property of State of Iowa, by \& through the State Historical Society of Iowa and its content may not be copied or emailed to multiple sites or posted to a listserv without the copyright holder's express written permission. However, users may print, download, or email articles for individual use. 